\title{
THE CONTRIBUTION MADE BY THE CROATIAN NATURAL HISTORY MUSEUM TO A BETTER INTERPRETATION OF THE CROATIAN NATURAL HERITAGE
}

\author{
RENATA BREZINŠČAK \\ Croatian Natural History Museum, Demetrova 1, HR-10000, Zagreb, Croatia \\ (e-mail: renata.brezinscak@hpm.hr)
}

\begin{abstract}
Brezinščak, R.: The contribution made by the Croatian Natural History Museum to a better interpretation of the Croatian natural heritage. Nat. Croat., Vol. 26, No. 1., 129-140, Zagreb, 2017.

Modern museums have an ever more important role in the implementation of programmes of cultural or natural tourism, for with their collections and exhibitions they attract increasing numbers of tourists and also encourage their visitors to set off into nature, to see the sites of the natural history. The Republic of Croatia has outstanding geological (rocks, minerals, fossils and relief) and biological diversity (the plant and animal worlds, habitats and ecosystems), and a little part of this is to be seen in the museum as well, which gives it great potential for interpretation of the natural heritage, and thus for tourism as well. The museum does keep and look after its heritage, but it also promotes it, together, then, with its city, region and country. The partnership between museum and tourism is today necessary for a given natural feature to be properly presented and preserved. There is particular importance in the networking of natural history museums with institutions related to the actual sites of natural features of interest (nature and national parks, geo-parks).
\end{abstract}

The paper shows how the museum in its programmes is oriented to the popularisation and interpretation of the natural beauties of the country. Along with the interactive map on the museum's web site, by touring the display and the exhibitions, through workshops, publications and other activities, the public can get to know some well known and less well known or entirely unknown and yet significant natural history sites. The programme partners are primarily schools, and after them, tourists. The Croatian curriculum is increasingly encouraging familiarity with natural history, the aim being systematic learning in the classroom and in nature as well, at the sites themselves. In the museum programme of presentation of the natural heritage for schools and tourists, sites are presented that have not only natural value and interest but are also easy, simple and safe of access, in other words, laid out for visitors.

Key words: museum, natural property, interpretation, visitors, schools, Republic of Croatia

Brezinščak, R.: Doprinos Hrvatskog prirodoslovnog muzeja boljoj interpretaciji hrvatske prirodne baštine. Nat. Croat., Vol. 26, No. 1., 129-140, Zagreb, 2017.

Moderni muzeji imaju sve veću ulogu u provođenju programa kulturnog i prirodoslovnog turizma, jer svojim zbirkama i izložbama privlače sve veći broj turista i potiču ih da se upute u prirodu i vide prirodoslovne lokalitete. Hrvatska je iznimno bogata geološkom (stijene, minerali, fosili i reljef) i biološkom raznolikošću (biljke, životinje, staništa, ekosustavi), a mali dio toga može se vidjeti i u muzeju, što čini veliki potencijal za interpretaciju prirodne baštine, a time i za turizam. Muzej čuva i brine o baštini, ali je i promovira, zajedno s pripadajućim gradom, regijom i zemljom. Partnerstvo između muzeja i turizma je danas neophodno da bi se neka prirodna znamenitost pravilno prezentirala i sačuvala. Posebno je važno povezati prirodoslovne muzeje s ustanovama koje brinu o pojedinim zaštićenim dijelovima prirode (nacionalni parkovi, parkovi prirode, geo-parkovi).

Rad prikazuje kako je muzej svojim programima usmjeren popularizaciji i interpretaciji prirodnih ljepota zemlje. Uz interaktivnu kartu na muzejskim web-stranicama, razgledavanjem postava i izložbi, 
kroz radionice, publikacije i ostale aktivnosti publika može upoznati poznate, manje poznate ili potpuno nepoznate, a opet značajne prirodne lokalitete. Partneri u tim programima su prvenstveno škole, a nakon njih turisti. Hrvatski nastavni plan sve više potiče upoznavanje prirodoslovlja, s ciljem učenja kako u učionici, tako i na samim lokalitetima. U muzejskom programu prezentacije prirodne baštine za škole i turiste, predstavljaju se lokaliteti koji imaju ne samo prirodoslovnu vrijednost, nego su i lako i sigurno dostupni, drugim riječima, kao osmišljeni za posjetitelje.

Ključne riječi: muzej, prirodoslovna znamenitost, interpretacija, posjetitelji, škole, Hrvatska

\section{INTRODUCTION}

What makes every country special is its heritage, both cultural and natural. Understanding one's own heritage is the foundation for understanding what one's nation has achieved, the particular features of one's own culture. The heritage is important too at a personal level, for it provides pleasure in the attainments of humanity and the beauties of nature. The heritage is what we inherit from the past, what lives today, what we hand on to future generations (UNESCO, 2016).

According to the UNESCO definition (UNESCO, 2016) natural history comprises natural characteristics consisting of:

- physical and biological formations or groups of such formations that are of exceptional universal value from an aesthetic or scientific point of view,

- geological and physiographic formations and exactly geographically defined areas that make up habitats of threatened species of animals and plants, also of exceptional universal value from the standpoint of science or preservation,

- natural features of interest or precisely geographically defined natural areas of exceptional universal value from the points of view of science, preservation or natural beauty.

The natural heritage covers the natural setting with its pertaining flora and fauna, which is often today called biodiversity. It is often employed as an important component in the tourist industry of some country, attracting a large number of visitors, both domestic and foreign. A heritage that has been preserved during history is often unique and irreplaceable, and entails the obligation of the next generation to preserve it as well.

Particular importance attaches to the Convention on the Protection of the World's Cultural and Natural Heritage, which in 1972 was accepted at a General Conference of UNESCO. Since then, 830 properties from the Republic of Croatia have been placed on the UNESCO World Heritage List, including 162 natural and 24 mixed properties (ANON, 2016). Nature and the protection of nature, says ŠPANJol (1997: 97), started to be bound up with tourism in conjunction with the development of transport and urbanisation. According to this author, the proclamation of the first national part in the world in 1872 (Yellowstone, USA) and the organisation of the first tourist trip around the world in the same year should be understood as causally related phenomena, not as fortuities. Since then tourism has developed relentlessly, bringing with it both advantages and disadvantages. Only in the mid-20 $0^{\text {th }}$ century, a hundred years later, did thinking start about the pernicious impact that tourism can have on nature (UNEP, 2016).

\section{The natural heritage of Croatia}

Because of its specific geographic position, BožıčEvić (1995/96: 17), the northwest and part of the western parts are more of an Alpine character, while the southwest and part 
of the western space are more of the Mediterranean character, and the northern part is subject to influences from the Pannonian basin. Location at the junction on various geographic areas resulted in Croatia having great natural diversity, both geological,geomorphological and biological (plant and animal worlds, habitats). Whatever place is visited or chosen for looking around or for relaxation, there is in the vicinity always some natural beauty, no matter whether it is part of a protected area (according to the Croatian legislative - national parks, nature parks, strict reserves, and so on), or whether it is just a landscape, a plant or suchlike. However, the question arises as to whether the general public knows this, or only dedicated lovers of nature. Do children and young people really know how attractive and interesting a country Croatia is? Many NGOs and associations that are engaged in the protection of nature do attempt to educate the public and bring this wealth to its attention. As the most recent example of such an attempt to bring attention to a part of Croatia's rich natural heritage is International Conference "Geodiversity, Geoheritage And Geoturism In Karst Areas" (BuzJAK \& PAAR, 2017). The main goal was to emphasize the role and values of geodiversity and geological heritage as a great source of information about natural diversity both in the past and in the present, and promote their research, evaluation, karst conservation, speleological objects characteristics, scientific activities and management.

But the museum too, as cultural institution, can also contribute to the better acquaintanceships with the natural heritage, making it more popular to visit and enjoy nature. It does this via various museum programmes, above all with exhibitions and its specialised and popular publications. Especially important role of the CNHM in the scientific research lies in the publishing its scientific journal Natura Croatica (since 1991), which has contributed a great deal to scientific and popular research into the natural heritage of Croatia. Numerous scientific biological and geological papers were published there about our endangered species of plants and animals, valuable results from floristic and faunistic research across Croatia, also from protected areas, national parks and nature parks, and areas significant for the Natura 2000, and with data from valuable museum collections (eg. a supplement about the ornithological collection kept in the CNHM (Grbac \& Kralj, 2008)

There are many areas in Croatia that deserve particular care and attention on account of their values, scientific, cultural, education, economic and aesthetic. Accordingly they must be protected, and nature and the parts of it that are particularly interesting to the Republic of Croatia are protected by the Nature Protection Law (Official Gazette, 89/13). Charged with the protection of natural values in the Republic of Croatia is the Ministry of the Protection of the Environment and Nature of the Republic of Croatia, and in turn the Directorate for the protection of nature and the Croatian Agency for the Environment and Nature. There are in Croatia 462 protected areas of nature, which, according to the Nature Protection Law, are classified into nine categories: strict reserve (2 areas), national park (8), special reserve (83), nature park (11), regional park (92), natural monument (116), significant landscape (80), forest park (38) and monument of park architecture (122). Some of the areas, because of their exceptional natural value, are internationally protected. They are:

- Plitvice Lakes National Park (UNESCO World Heritage List, first Croatian nationa park established in 1949),

- Kopački rit and Lonjsko polje Nature Parks, the special ornithological reserves the Crna Mlaka fishponds and the lower course of the Neretva River (Ramsar List of the Wetlands Convention), 
- Velebit Nature Park (already since 1978 in UNESCO's International Network of Biosphere Reserves 'Man and the Biosphere')

- the cross-border biosphere reserve Mura-Drava-Danube (Croatia/Hungary)

- Papuk Nature Park (GEOPARK).

There are more than 7,500 square kilometres of protected space, or about $8.6 \%$ of the entire area of Croatia. Also protected by the law are some plants and animals, as well as minerals, ores and fossils. Apart from that, some of the areas are in the ecological network of the Republic of Croatia, which is a Natura 2000 area, i.e., part of the ecological network of the EU, which consists of the most important areas of nature for the preservation of species and habitat types. The ecological network of the Republic of Croatia covers $36.73 \%$ of its land area and $15.42 \%$ of the coastal sea (Official Gazette, 124/13 and $105 / 15)$.

\section{DISCUSSION}

\section{Museum and national heritage}

According to the definition of the Charter of the International Museum Organisation (ICOM, 2007) ,, a museum is a non-profit, permanent institution in the service of society and its development, open to the public, which acquires, conserves, researches, communicates and exhibits the tangible and intangible heritage of humanity and its environment for the purposes of education, study and enjoyment". According to ŠolA (2001: 64) museums are devised according to human requirements, the needs of the society and community in which they work. Kiersten \& Simmons (2014: 73) say that the natural objects that are kept in natural history museums are assembled in line with systematics (zoological, botanical and mineralogical and so on for the purpose of creating representative collections that are not only useful for scientific purposes but should also be suitable for the understanding of the nature around us. Modern museums are oriented towards the interpretation and popularisation of natural history and have an increasingly important role in delivering programmes of cultural and natural tourism, for with their holdings, collections and exhibition programmes they attract increasing numbers of visitors and tourists, and are also capable of directing their visitors to sites of cultural and natural heritage. Acquaintanceship with the heritage is important not only for all those who visit the country, but for its own inhabitants. Today the phrase cultural landscape is increasingly used, which means a spatial system, a geographical area of recognisable characteristics, created as a result of the interaction of people and their natural surroundings. Its most diverse features, like topography, vegetation cover, land use, settlements and buildings are interpreted and viewed through the actions of complex factors, whether natural or social (Official Gazetre, 12/2002).

Can a museum contribute to a better knowledge of the natural heritage, and if so, how? In Croatia there are five natural history museums - in Zagreb, Rijeka, Split, Metković and Dubrovnik. In addition, there is a special zoological museum, the Malacological Museum in Makarska. Krapina has its special geological and palaeontological museum - the Museum of Krapina Neanderthals. There are natural history departments in the National Museum, Zadar; the Museum of Slavonia, Osijek; and Varaždin Municipal Museum has a very interesting and attractive entomological department. Many city and local history museums as well as private museums feature natural history collections in their displays. 
The Croatian Natural History Museum in Zagreb is one of the oldest with respect to its collections, and with respect to the size of its holdings is the biggest, and is the reference natural history museum in Croatia. The whole activity of a natural history museum (acquisitions, research, exhibition, scientific) is directed to acquainting the public with nature and the need for its preservation and protection. The museum abounds with interesting exhibits, hence along with attractive exhibits of prepared animals, visitor attention is also drawn to exhibitions from the Croatian karstic subterranean area, its minerals, rocks and fossils. The museum, then, is certainly worth a visit.

The question will arise as to how museum exhibits can help in the interpretation and promotion of the natural heritage and encourage people to visit natural beauties (and through that conscientise them to the necessary for preserving and protecting nature). The museum does this in its programmes, primarily its exhibitions, for the exhibits attract the attention of visitors and indirectly encourage them to get out into nature and visit the area where the given natural object was found (if it is about minerals and fossils), or where it lives (if animals and plants are concerned). So exhibitions are used to inform visitors and to prompt them to form the idea of going to see the actual sites. In this direct or indirect orientation, in the captions at the exhibition or on the internet site there should certainly be remarks about the accessibility of the actual site, or whether it is appropriate for ordinary tourists or only for the more adventurous.

Museum programmes also promote the natural heritage and encourage this kind of tourist product, but with a deal of caution and mentioning the necessary measures to be applied in line with the preservation of the natural heritage. The basic problem of today is to achieve some balance between development and the preservation of nature and the environment, which is threatened with devastation from big development and from the high number of tourists. The more tourists there are, the greater the development needed, thinks ŠPANJol (1997: 99). It is important then to mention that the concept of linking museum programmes and tourist destinations must be at the service of sustainable development, protection of nature and the environment. According to KušEN (2002: 3) "the space and the environment are immanent to the concept of tourism and inversely the idea of tourism is inconceivable without the components of space and environment". The idea of a new approach to protection of the environment according to which on the one hand development is permitted and space protected on the other was accepted in Croatia in 1994, at the international scientific conference "Towards the sustainable development of tourism in Croatia" (KLARIĆ, 1994).

\section{Collections, displays, exhibitions, research}

The museum collections of the Croatian Natural History Museum are documents of the development of that part of the Earth in which Croatia lies. Today the museum has about 2 million natural objects from Croatia and neighbouring countries, and from many parts of the world, even from outer space (meteorites). Part of this wealth is displayed in the permanent displays or is shown in occasional thematic exhibitions in which we try to acquaint the visitors with valuable collections, important natural historians or features of interest from the natural heritage or its protection and so on.

A tour of the museum starts in the atrium with the geological column and a stylised geological map of the Republic of Croatia composed of stone that originates from each individual region. Thus at the very entrance to the museum, the visitor is shown all the geological diversity of the country. In the displays and exhibitions it is mostly Croatian 
natural objects that are shown - rocks, fossils and prepared animals, while in the temporary, thematic, photographic exhibitions the landscapes are promoted. It is landscape, thinks MüLLER (2004: 91) that is one of the most important elements of the tourist product, and flora and fauna contribute to that importance, especially endemic species.

In the last few years geological forms have become interesting too (the basalt columns on Papuk, the cliffs of Dugi Otok, the cascades of Plitvice, the volcanic beach on Vis, the site of Krapina pre-historic man, the finding site of the precious stone agate by Lepoglava and various caverns). All of these attract tourists. In the world at large, and to a small extent here too, organised specialised tours are increasingly popular, particularly to do with botany (for example, looking around the spring flowers, orchid trails, botanical gardens) and geological (visits to geological phenomena in Lika, jewel trails around the Urals, visits to caves) or for example diving for the purpose of observing the submarine biodiversity (MüLLER, 2004: 105). The museum precisely with its exhibits shows what can be seen in Croatia, and where, and hence if someone wonders at the beauty of the Lepoglava agate on display, or at the griffon vulture, this can certainly be an impulse to visitors, particularly tourists, to set out, either in a group or on their own, into nature and to look at the site from which the mineral agate comes, or to see live the habitat of a given animal or plant, and to enjoy a given landscape. The museum, as establishment that promotes the protection of nature, naturally privileges scientific research and education as kinds of tourist activity. It is important to know what to look at, for only if one knows the kind of natural value that is concerned and what it means for our continued existence can it really be appreciated. The role of the museum in this is to show what it possesses, why it is important, particular in terms of science or culture, where it is to be found, and whether it is possible to get to the given destination, and if so, how.

Still, thematic exhibitions most prompt visitors to get out into nature. All the exhibitions are accompanied by appropriate catalogues that can be purchased in the museum, and additional programmes are organised such as lectures, workshops, round tables, panel discussions and so on.

The Croatian Natural History Museum became involved in the interpretation and promotion of the natural heritage in 1995, when the Republic of Croatia first was involved in the European Heritage Day, when the photographic exhibition On Podrava Sands by R. Kranjčev and M. Crnjaković was put on. The exhibition was created in order to encourage the understanding of the human relationship with the natural heritage as a part of the cultural identity (KRANJČEv \& CRNJAKović, 1995: 13). Photography is used as document and as means of aesthetic expression. The theme of the exhibition was a particular sandy part of Croatia that is called the "Croatian Sahara", and the distinctive grassland community and animals that live on these sandy soils. Because of all this, it is a very popular destination for school trips. Not only can the sand dunes and the sand be seen, but there are unique examples of the plant and animal world that contribute to the richness of the biological diversity of Croatia. The habitat is protected as a special botanical reserve.

The first really large exhibition of the CNHM the objective of which was not only to present the specialised material that the museum had inherited (the collections) but to get the visitors interested in getting out into nature was the Medvednica Eco-Museum, put on in 1997. In this exhibition, its creators, D. Bukovec, N. Tvrtković, M. Vrbek (CNHM), Z. Gregl (Archaeological Museum, Zagreb) and V. Zorić (Ethnographic Mu- 
seum, Zagreb) wanted to enable visitors to have a pleasant and informative encounter with Mt Medvednica, with its natural history, archaeological, ethnographic and cultural phenomena (Vuкоvić \& Buкоvec, 1997). In the introductory part of the catalogue, the authors say: „Hence, if this exhibition, together with its catalogue, enables a better knowledge of Medvednica, if it encourages those who do not often visit it to set off at least occasionally... then we have succeeded in our intention" (Vuković \& Bukovec, 1997: 2). Precisely for this reason the catalogue of the exhibition was prepared as a guide to be taken with one on a stroll around Medvednica, and contained a handy map and photographs of the major cultural and natural history features of this mountain.

M. Crnjaković's Volcanoes on the Adriatic Islands? is an example of an exhibition that in its theme and the exhibits shown definitely encourages visitors to go and tour the islands, to look on the spot at the remains of the activity of ancient volcanoes, a unique phenomenon in the Adriatic Sea (CRNJAKović, 1998), enjoying as they do the unspoiled natural landscapes of this island. The exhibition was put on in Komiža on Vis Island in 1998, in the CNHM in 1999, and in the NHM in Split in 2000.

Photo-exhibition Zrmanja - Hidden Beauty, devised in Obrovac in 2001 by N. Tvrtković, V. Štamol, G. Lukač, B. Jalžić, D. Lacković and M. Crnjaković, and especially its catalogue (Vuкоvić, 2001), brought photographs of the Obrovac area, unknown to many. It was a great advertisement for this part of the Velebit Nature Park, a pearl in the national heritage ideal also for adventure tourism (climbing, rafting).

Exihibitions like Stone formations of Velebit, by S. Japundžić in 2005, are precious for mountaineers, hikers and naturalists. Old black and white photographs from the legacy of dr. Josip Poljak were displayed (JAPUnDžıć, 2005), showing protected areas of Mt. Velebit as they once looked like, offering us a comparison with how they look today.

A good interpretation of the natural heritage can be achieved with the presentation of documentary natural history photography. One of the pioneers in such photography is Vladimir Pfeifer, whose works were shown at the exhibition Ars Naturae Monumenta Croatica Fauna \& Flora, 2007, by R. Brezinščak. The exhibition was shown first in Zagreb, then all around Croatia, and in the Czech Republic, and several times in Hungary. The big enlargements helped to make the exhibition so impressive. The motifs of the photographs - the plants, animals, the landscapes and seascapes and underwater scenes were show in somewhat fairytale moments, all as it were inviting a trip out into nature, for personal experience of the fairy tale, or, on the contrary, to see how the natural landscapes are changing as a result of the every greater development.

The exhibition devised by D. Holcer Islands - Places of the Love of Sea and Land was put on in the CNHM in 2014, and then in Metković and in Montenegro. It presented the huge biodiversity of this area, of interest to both scientists and tourists, and the captions of the exhibition were written in two languages. The exhibition provided the information that the Republic of Croatia has 718 islands and islets, that islands are the main areas in which evolution is studied, and that today, according to information from the International Union for the Conservation of Nature (IUCN), 80\% of recently extinct species are actually those that lived on islands. Forty-five percent of the threatened species on the IUCN Red List live today on islands (HoLCER, 2014). Islands have an important role in biological diversity in marine ecosystems. Along with gorgeous photography, the museum showed some 30 museum preparations, quite enough for everyone who viewed the exhibition to decide to visit one of the islands presented and enjoy the sight of rare animals and plants. 
Visitors of Zagreb, but also its inhabitants, found exhibition Through the streets of Zagreb - Zagreb in stone devised by K. Krizmanić, D. Japundžić and N. Prlj Šimić in 2014 an exceptional example of how an exhibition can inspire city inhabitants and tourists to take notice of the building material of certain famous buildings and to find out a lot of interesting facts from it (KRIZMANić et al., 2014).

Examples of good practice are exhibitions that are accompanied by catalogues that are also guides. The exhibition The Mineral Realm (Radanović Gužvica \& Buкovec, 2011) was opened in the CHNM in 2011, as part of the new permanent display. As the authors said in the preface, the catalogue that accompanied the exhibition was a guide not only to the exhibition but "could be of assistance to lovers of nature who find an example of some mineral in the field." Apart from that, in an ancillary programme, there were guided trips into nature, mostly into Hrvatsko zagorje, to the site of the mineral agate. Along with the exhibition Threatened Flora and Fauna of the City of Zagreb (TVrTKović, 2010), put on in the CNHM in 2010, there was an accompanying programme that was very well received by visitors. To accompany the exhibition, a booklet with the subtitle A Pocket Natural History Guide was printed, made as a practical guide for identifying plants and animals of the Zagreb region that are particularly threatened and that are likely to disappear. As at the exhibition, in the booklet too, the plants and animals are presented with photographs, for them to be easily identified, along with key information about their threat level and protection, distribution and ecology, and the threat level in Zagreb. The exhibition was created out of the desire to awake in schoolchildren an interest in the life around them.

These booklets were made to be species identification keys, with pictures and a short description of each species, for them to be identifiable in nature. Made to fit into a pocket, they can be taken easily on field trips, amateur naturalists thus being enabled to observe and to know the nature around them. Another practical pocket edition is the Mineralogical Guide to Medvednica (Č EPELAK et al., 2001) meant for amateur mineralogists who, walking along the hillsides of Medvednica, can uncover "the speciously hidden world of minerals".

As well as these pocket guides to natural objects, the Museum has also published the Tourist Guide - Map of Geological and Biological Features of Interest of Croatia (BREZINŠČAK, 2009) which promotes sites and landscapes. The map is printed on two sides, in colour, with photographs of 35 natural attractions, alongside which there is additional information about why a given site is important, what to look at and how to get to it. The map is meant for schools, as an aid in the selection of destinations for school excursions, and for families and tourists.

Most of the exhibitions are really designed for adults, but children too should be acquainted with the natural heritage. Intended for children, then, were exhibitions in which it was learned what nature is, who lives in it, and concepts from nature are explained (water, ecology and so on). Schools in Croatia organise weeklong stays in nature for schoolchildren called "Nature School". A part of this programme is the work together with a natural history museum. The wish is for children not only to stay in nature, but to have a stay that is professionally devised. The Museum has issued a booklet or manual called Minerals, Rocks, Fossils - a Manual for Junior Collectors (BREZINŠČAK, 2012), aimed at encouraging them to observe in nature. By observing and collecting natural objects, they can create natural history collections and study what has been collected, at home or in school. For this purpose, children can acquire some preliminary 
knowledge taking part in workshops in the museum itself or in the field, in nature. Such programmes, workshops, leaflets and booklets and so on all contribute to a better interpretation and popularisation of the natural heritage and in this manner children and young adults with a series of creative and research activities, are oriented to the need to preserve nature. Making, for example, posters or bookmarks, playing memory, jigsaw puzzles, through creative work, then, children master knowledge about the natural history of their country.

It was mentioned earlier that museums are today very much engaged factors of the society, which endeavour with their work to contribute to the development of the community. Issues of the proper evaluation and preservation of the heritage have become a global theme, and in 2016, the international museum organisation ICOM, the umbrella organisation that brings together museums of the whole world, took the theme "Museums and the Cultural Landscape" as its theme for the $24^{\text {th }}$ General Conference. Taking part in the conference were 3500 museum professionals from 130 countries (http:// network.icom.museum/icom-milan-2016//). At the same time, this was the recommended theme for various activities that all museums in the world organised that year to mark International Museums Day.

Another programme that enables visitors to the museum to interpret the natural heritage is "Out of the Museum to Medvednica", later expanded to "Out of the Museum to Nature", in which at certain sites the importance of the natural heritage and its preservation is explained. The objective of the programme (devised by the museum curator and mineralogist D. Lacković) is to let visitors to the Museum have a direct experience of natural values in trips into nature. These are learning excursions into nature guided by curators who inform visitors about natural objects and phenomena that they come upon during the trip. Guided excursions are organised in spring and autumn and are adjusted to various age groups. Before every excursion, popular science lectures and workshops are organised in the museum; the children complete assignments, explore the display and look over some of the natural objects that they will see in real life on the trip.

\section{Web sites}

Today, the Internet is an irreplaceable source of all information and knowledge. The CNHM (HPM) site (www.hpm.hr) gives brief information about the museum collection, photographs of some of the more important objects from the collections, provides an acquaintanceship with the natural heritage and educational interactive contents. An important part of the Internet site is an interactive map of geological and biological features of interest in Croatia for tourists (hpm.hr/interaktivna-karta) that, making use of Google Maps, enables users to get to know 35 natural history, geological and biological features of interest in the Republic of Croatia. This is an expanded and supplemented version of the printed map (which contains photographs of sites and information about why the site is important and how it can be reached, links to institutions and organisations important for the natural heritage). The advantage of the interactive map over the printed version is above all in its being used by a larger number of users, particularly those outside Zagreb, for they can find out which feature of interest is located close to them, or, after searching for all the features, decide which one to visit. In this programme, institutions associated with the museum are the national parks, nature parks and associations that take care of given sites. 


\section{Souvenirs and memorabilia}

Although they might seem trivial, souvenirs have real importance. All visitors like to take away something to remind them of what they have seen and experienced. In this lies the importance that souvenirs have in the promotion of the natural heritage. The importance of the natural heritage cannot be conveyed only by the one-time information that visitors obtain in a museum, for it has to be an integral part of our lives. At the exhibition, visitors get the basic information. If they want to know more, they can find out through expert museum publications and various souvenirs obtainable in the museum. In addition to the guides and maps already mentioned, available for visitors are thematic publications related to given sites, sometimes published in association with local natural history societies or tourist boards. Some of them are - the Nature of the Karstic poljes, the Primeval Pag Lake, Palagruža - Magical Oasis in the Open Sea, Turopolje - A Vanishing World, Natural Contrasts of Mljet Island, Birds of the Croatian Adriatic Coast... and so on., as well as posters, magnets, T-shirts with printed nature protection slogans, picture postcards of threatened animal and plant species.

\section{CONCLUSION}

At a time of growing globalisation, the interpretation and presentation of cultural and above all natural diversity are an important challenge for all, particularly for museums, making the country a magnet in the globalised market. Most important for museums are visitors. The Croatian Natural History Museum is mostly visited by school groups, and they are the main partners in the programme of interpreting and popularising the natural heritage. In the Croatian curriculum there are increasing numbers of programmes directed towards the natural heritage, the aim of which is that children be systematically familiarised with the heritage in school, in nature at the sites themselves, as part of the obligatory school trips and learning in nature. Programmes in the museum then have to provide them interesting, satisfying and fulfilling experience. A museum has to be a place where it is possible to acquire extra information about the chances of discovering similar contents in nature; where one can get information about what there is to be seen and, ultimately, how to get there. Naturally, it would be interesting to create a platform that includes service providers such as travel agency and tour operators to organise specialised natural history excursions. In association with museums and expert museum staff, in this way visitors would be provided well-informed and reliable as well as handily organised acquaintanceship with the nature and environment in which we live. This would achieve the aim of the natural heritage being accessible and intelligible to all.

Received February 20, 2017

\section{REFERENCES}

BožıčEvić, S., 1995/96: Položaj, klima, tlo, vode i specifičnosti površinskih oblika. U Zdunić, D. (ur.): Prirodna baština Hrvatske, 17-26, Buvina, Zagreb.

BrezinšČAK, R., 2007: Vladimir Pfeifer - Ars Naturae Monumenta Croatica Fauna \& Flora. Hrvatski prirodoslovni muzej, Zagreb.

BrezinšČAK, R., 2009: Vodič - karta geoloških i bioloških turističkih znamenitosti Hrvatske. Hrvatski prirodoslovni muzej, Zagreb. 
BREZINŠČAK, R., 2012: Minerali, stijene, fosili - priručnik za male sakupljače. Hrvatski prirodoslovni muzej, Zagreb.

BuzJaK, N. \& PAAR, D. (eds), 2017: Book of Abstracts. International Conference „Geodiversity, Geoheritage And Geoturism In Karst Areas”, Perušić, 18.-19.2.2017. Sveučilište u Zagrebu, Prirodoslovno-matematički fakultet, Geografski odsjek \& Javna ustanova za upravljanje zaštićenim područjima i drugim zaštićenim dijelovima prirode na području Zagrebačke županije „Zeleni prsten”, Samobor

CRNJAKović, M., 1998: Vulkani na jadranskim otocima? Katalog izložbe, Hrvatski prirodoslovni muzej, Zagreb.

Čepelak, M., Malinar, H., ZagorščaK, D. \& Zebec, V., 2001: Mineraloški vodič po Medvednici, Hrvatski prirodoslovni muzej, Zagreb.

Grbac, I. \& KRALJ, J., 2008: The catalogue of the bird collection of the Croatian Natural History Museum. Natura Croatica 17, Suppl. 1, 1-226.

Holcer, D., 2014: Otoci / Islands. Katalog izložbe, Hrvatski prirodoslovni muzej, Zagreb.

JAPUNDŽı́c, S., 2005: Kameniti oblici Velebita. Katalog izložbe, Hrvatski prirodoslovni muzej, Zagreb.

Kiersten, F.L. \& Simmons E. J., 2014: Foundations of museum Studies - Evolving systems of knowledge, Librarires Unlimited, St. Barbara, Cal. USA.

KLARIĆ, Z. (ed.), 1994: Međunarodni znanstveni skup Prema održivom razvitku turizma u Hrvatskoj : zbornik radova $=$ International scientific round table Towards sustainable tourism development in Croatia : proceedings of the scientific round table / Institut za turizam, Zagreb.

Kranjčev, R. \& CRnjaKović, M., 1995: Na podravskim peskima. Katalog izložbe, Hrvatski prirodoslovni muzej, Zagreb.

Krizmanić, K., Japundžıć, D. \& PrLJ Šimić, N., 2014: Zagrebačkim ulicama... Zagreb u kamenu. Katalog izložbe, Hrvatski prirodoslovni muzej, Zagreb.

KušEN, E., 2002: Turizam i prostor, klasifikacija turističkih atrakcija, Prostor: znanstveni časopis za arhitekturu i urbanizam, Vol. 9, No.1 (21).

Mû́LLER, H., 2004: Turizam i ekologija. Masmedia, Zagreb.

Official GaZette, 2002: Zakon o potvrđivanju Konvencije o europskim krajobrazima, Narodne novine 12 , Zagreb

Official Gazette, 2013: Zakon o zaštiti prirode. Narodne Novine, 89/13.

Official Gazette, 2013: Uredba o ekološkoj mreži. Narodne Novine, 124/13.

Official Gazette, 2015: Uredba o izmjenama Uredbe o ekološkoj mreži. Narodne Novine, 105/15.

Radanović GužvicA, B. \& BuKovec, D., 2011: Carstvo minerala. Hrvatski prirodoslovni muzej, Zagreb.

ŠolA, T., 2001: Marketing u muzeju ili o vrlini i kako ju obznaniti, Hrvatsko muzejsko društvo, Zagreb.

ŠPANJoL, Z., 1997: Turizam i zaštita prirode i čovjekova okoliša, Socijalna ekologija : časopis za ekološku misao i sociologijska istraživanja okoline, Vol. 6, No.1-2, Zagreb.

TvrTKović, N., 2010: Ugrožena flora i fauna grada Zagreba. Hrvatski prirodoslovni muzej, Zagreb.

Vuкović, M. (ed), 2001: Zrmanja - Hidden Beauty. Exhibition catalogue. Croatian Natural History Museum \& Public Open University Obrovac.

Vuкоvıć, M. \& Buкоvec, D. (eds), 1997: Medvednica - eko muzej. Katalog izložbe, Hrvatski prirodoslovni muzej, Zagreb.

UNESCO, 2016: Convention Concerning the Protection of the World Cultural and Natural Heritage (pristupljeno 5.12.2016).

Internet sources:

http://whc.unesco.org/en/about/ (5.12.2016.)

http://whc.unesco.org/en/conventiontex (5.12.2016.)

http://www.min-kulture.hr/default.aspx?id=5 (16.12.2016.)

http://www.mzoip.hr/hr/priroda/zasticena-podrucja.htm (12.12.2016.)

http://www.icombih.org/site/definicija-muzeja,19.htm (15.12.2016.)

http://www.hpm.hr (12.12.2016.)

http://www.botanica.travel/travel-themes/wildflowers (4.12.2016.)

https://hr.rbth.com/travel/2014/05/10/putevima_dragulja_geoloski_turizam_na_uralu_2724 (4.12.2016.)

http://www.hpm.hr/Doga\%c4\%91anja/Doga\%c4\%91anje/Iz\%20muzeja\%20u\%20prirodu\%20-\%20 jesen\%202016._371 (10.12.2016.) 
http://www.enciklopedija.hr/Natuknica.aspx?ID=2639 (6.12.2016.)http://www.hpm.hr/interaktivna-karta (10.12.2016.)

http://www.hpm.hr/Odjeli\%20i\%20zbirke (26.11.2016.)

http://www.hpm.hr/Publikacije\%20i\%20suveni (26.11.2016.)

http://www.unep.org/documents.multilingual/default.asp?documentid=97\&articleid=1503 (20.12.2016.)

http://www.hpm.hr/Doga\%c4\%91anja/Doga\%c4\%91anje/Iz\%20muzeja\%20u\%20prirodu\%20-\%20 jesen\%202016._3714 (15.12.2016.)

http://icom.museum/news/news/article/24th-icom-general-conference-in-milan-3500-museum-professionals-130-countries/ (20. 12. 2016.) 